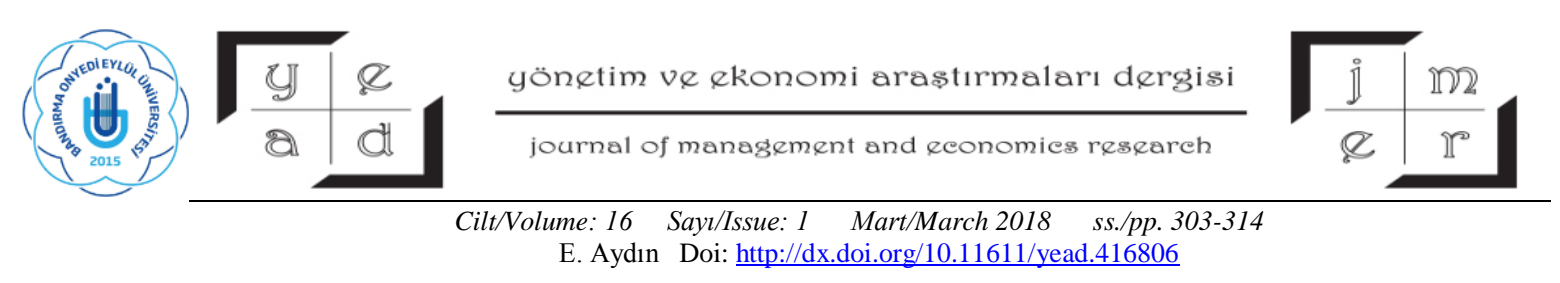

\title{
THE IMPACTS OF CAPITAL INTENSITY AND R\&D SPENDING ON MANUFACTURING INDUSTRY VALUE ADDED IN INDUSTRY 4.0 PROCESS: A PANEL DATA ANALYSIS
}

\section{Asst. Prof. Dr. Erdal AYDIN"}

\begin{abstract}
Industry 4.0 or 4th Industrial Revolution is a phenomenon, which is being discussed more day by day all around the world, and it is undoubtedly a fact to be taken into consideration with all aspects of the situation because it is the latest generation of the revolutions. From this perspective, in this paper, the relationship between drivers of production of industry 4.0 and manufacturing value added that is the core of economic development/growth is determined using panel data covering the nine leading countries in the industry 4.0 process over the period 1996-2015. Empirical results of this study was applied by the Dumitrescu-Hurlin (2012) panel Granger causality test, which takes into account cross-sectional dependence indicate one-way causality from capital intensity to manufacturing value added, two-way causality between R\&D expenditures as a share of GDP and manufacturing value added in the selected country group. In addition, empirical findings showed that greater capital intensity and $R \& D$ expenditures of GDP, which are the input variables of industry 4.0 process significantly increase manufacturing value added, which is the one of the output variables of the process.
\end{abstract}

Keywords: Industry 4.0, Technological Progress, Panel Causality

JEL Codes: C33, L52, 032.

\section{ENDÜSTRİ 4.0 SÜRECINDE SERMAYE YOĞUNLUĞU VE AR-GE HARCAMALARININ IMMALAT SANAYİ KATMA DEĞERİ ÜZERİNDEKİ ETKİLERİ: PANEL VERİ ANALİZI}

ÖZ

Endüstri 4.0 yada 4. Sanayi Devrimi, dünyanın her yerinden gün geçtikçe daha fazla tartışılan bir olgudur ve kuşkusuz, durumun tüm yönleriyle ele alınması gereken bir gerçektir, çünkü bu, devrimlerin son neslidir. Bu açıdan bakıldiğında, bu çalışmada, sanayinin 4.0 üretim faktörleri ile ekonomik gelişmenin / büyümenin çekirdeğini oluşturan üretim katma değeri arasındaki ilişki, 1996-

*Çanakkale Onsekiz Mart University, Biga Faculty of Economics and Administrative Sciences, Department of Business, mailto:erdalaydin@comu.edu.tr 
Yönetim ve Ekonomi Arastırmaları Dergisi / Journal of Management and Economics Research

Cilt/Volume: $16 \quad$ Sayl/Issue: $1 \quad$ Mart/March 2018 ss./pp. 303-314

E. Aydın Doi: http://dx.doi.org/10.11611/yead.416806

2015 dönemi boyunca sanayinin 4.0 sürecindeki dokuz önde gelen ülkeyi kapsayan panel verileri kullanılarak belirlenmiştir. Yatay kesit bağımlılı̆̆ını dikkate alan Dumitrescu-Hurlin (2012) panel Granger nedensellik testinin uygulandı̆̆ı çalışmanın ampirik sonuçları, seçili ülkelerde sermaye yoğunluğundan imalat sanayi katma değerine doğru tek yönlü, AR-GE harcamalarının GSYiH içindeki payı ile imalat sanayi katma değeri arasında ise çift yönlü nedensel ilişkilerin olduğunu göstermektedir. Ayrıca, ampirik bulgular, sanayi 4.0 sürecinin girdi değişkenlerinden olan sermaye yoğunluğu ve Ar-Ge harcamalarının, imalat sanayi katma değerini önemli ölçüde artırdı̆̆ını göstermiştir.

Keywords: Endüstri 4.0, Teknolojik Süreçler, Panel Nedensellik

JEL Codes: C33, L52, 032.

\section{INTRODUCTION}

Since the beginning of the industrialization, technological leaps have led to paradigm shifts in production systems, nowadays called "industrial revolutions". Industry 4.0 or 4th Industrial Revolution is a phenomenon, which is being discussed more day by day in world countries, and it is undoubtedly a fact to be taken into consideration with all aspects of the situation because it is the latest generation of these revolutions.

A thirty-year follow-up to the first industrial revolution (Industry 1.0) which included the mechanization of the transformation water into vapor power, the first electric-powered assembly line was serialized and thus the second industrial revolution (Industry 2.0) took place. In the late 1960s, the first programmable logistics controller (PLC) opened the doors of the third industrial revolution (Industry 3.0) by enabling the automation of production through the use of electronic and IT systems www.plex.com,2016). In this chronological process, the faster the countries are adapting to these revolutionary battles, the better they will be able to have the chance to increase their welfare. Undoubtedly, the advantages of capturing these revolutions (or the disadvantages of missing the opportunities of them) have an important place in the classification of developed, developing and underdeveloped countries, which are frequently used today.

Industrial 4.0 or $4^{\text {th }}$ Industrial Revolution is generally defined as the application of cyberphysical systems into industrial production systems (Drath, Alexander, 2014; 56). The increasingly competitive environment created by information technology and globalization with high acceleration in the 2000s has radically differentiated the value creation activities of countries and nations and has led them to progress by renewing themselves. To this end, firstly, Germany developed the concept of Industry 4.0 to bring itself to a new and privileged position. 
Yönetim ve Ekonomi Arastirmaları Dergisi / Journal of Management and Economics Research

Cilt/Volume: $16 \quad$ Sayl/Issue: $1 \quad$ Mart/March 2018 ss./pp. 303-314

E. Aydın Doi: http://dx.doi.org/10.11611/yead.416806

The theoretical beginning of the Industry 4.0 case is Kagermann's famous article " Industrie 4.0: Mitdem Internet der Dinge auf dem Wegzur 4. industriellen Revolution " which was published in 2011. Here Kagermann states that the $4^{\text {th }}$ Industrial Revolution includes not only the development in automation, but it also includes the intelligent observation and decision making processes. Although the basic idea was put forward by Kagermann, the theoretical framework of this concept brought into consideration when the German National Academy of Science and Engineering published the "manifesto" in 2013 (Alçın, 2016; 63).

Speaking of the line between the last two revolutions, Industry 3.0 focuses on the automation of machines and processes alone, while Industry 4.0 focuses on end-to-end digitization of all physical assets and integration with digital ecosystems alongside value chain partners. The creation, analysis and transmission of data provide a seamless basis for the Industry 4.0's promises, which links a wide range of new technologies to the network in order to create value (www.pwc.com, 2016).

\section{THE ORETICAL PERSPECTIVE}

Industry 4.0 refers to a combination of many important technological innovations that are being mature at the same time and are expected to significantly change the look of the manufacturing industry. These technologies - advanced robotics, artificial intelligence, advanced sensors, cloud computing and big data analysis - will exist in some form in today's manufacturing, but will connect and transform the industry when physical and virtual worlds are integrated with each other (www.plex.com, 2018).

Industry 4.0 generally consists of three structures that can be counted as internet of objects, internet of services and cyber-physical systems (www.endüstri40.com, 2018). The industry 4.0 design will be created with more advanced synchronization and integration which to be built with these three structures. Industry 4.0 is characterized by the ability to perform real-time communications, connections and definitions between people, machines and products and to develop a specialized and digitized intelligent manufacturing model that is highly customizable to customer requirements with a high degree of flexibility. The transformation of production from centralization to localization, the conversion of the product from uniform to personalized, and the ability of the users to participate fully in production, rather than partial participation are at the core of this smart manufacturing model. This requires a large ICT (Information Communication Technologies) adaptation of the manufacturing industry as well as the use of structures known as cyber-physical production systems (SFS), which combine the boundaries of the real world with the possibilities of the virtual world (www.researchgate.net, 2018) . 
Yönetim ve Ekonomi Arastırmaları Dergisi / Journal of Management and Economics Research

Cilt/Volume: $16 \quad$ Sayl/Issue: $1 \quad$ Mart/March 2018 ss./pp. 303-314

E. Aydın Doi: http://dx.doi.org/10.11611/yead.416806

Although the Industry 4.0 concept was originally only used for production (as opposed to Industrial Internet and Industrial Internet Consortia or other leading initiatives such as IIC), we can say that it actually went even further. Today, we can mention that a few sides in Industry 4.0 are giving direction to this phenomenon towards smart transportation and logistics, intelligent building, oil and gas, intelligent health services and even smart cities (https://www.i-scoop.eu/industry-4-0).Only 25 countries well-positioned to benefit from Industry 4.0 according to new World Economic Forum report. These are Austria, Belgium, Canada, China, Czech Republic, Denmark, Estonia, Finland, France, Germany, Ireland, Israel, Italy, Japan, Republic of Korea, Malaysia, Netherlands, Poland, Singapore, Slovenia, Spain, Sweden, Switzerland, United Kingdom and United States.

The importance and positive impact that Indusrty 4.0 will bring into production- in this manner, directly to manufacturing value-added- can be summarized as follows (Öztürk, Koç, 2017;183):

- More automation in manufacturing, mass production that is more connected to customer preferences, maximum manufacturing quality, localized manufacturing processes, rapid innovation process and less resource use

- More flexible and free system and application possibilities for production processes

- Extraction of the high cost of producing completely personalized products for customers to minimum levels

- Simplification of logistics operations by increasing data transmission speed and enabling products to be produced at closer centers by means of 3D printers

- Efficient use of energy resources

\section{EMPIRICAL ANALYSIS}

This paper constitutes an econometric model to show the causal relationships among R\&D expenditures as a share of GDP, capital intensity and manufacturing value added of the nine countries that well-positioned to benefit from Industry 4.0 according to new World Economic Forum report during the period 1996-2015. The Dumitrescu-Hurlin panel non-causality test is performed for the presence of the causal relationships between the variables.

\subsection{Model and Data}

In the analyzing of the relationship between $R \& D$ expenditures as a share of GDP, capital intensity and manufacturing value added by incorporating a balanced panel from the nine leading countries in the industry 4.0 process this study considers the linear panel data specification as follows:

$$
L M V A_{i t}=\delta_{0}+\delta_{1} L C A P_{i t-1}+\delta_{2} L R D_{i t}+u_{i t}
$$


Yönetim ve Ekonomi Arasttrmaları Dergisi / Journal of Management and Economics Research Cilt/Volume: $16 \quad$ Sayl/Issue: $1 \quad$ Mart/March 2018 ss./pp. 303-314

E. Aydın Doi: http://dx.doi.org/10.11611/yead.416806

Where MVA, CAP and RD are manufacturing value added, capital intensity and R\&D expenditures as a share of GDP, respectively. The annual data is used. The data covers the period of 1995 to 2014 derived from World Bank's World Development Indicators (2015). This sample is selected based on the data availability. The countries dealt with in this study are United States, Singapore, Netherlands, Sweden, Germany, United Kingdom, Denmark, Switzerland, and Hong Kong.

Table 1 presents the variables used and their descriptive statistics. The cross-sectional dimension is 9 units and the time dimension is 20 years. In total, there are 180 observations for the all variables. According to Table 1, the means of LMVA, LCAP and LRD are close neither to their minimum nor maximum value. Hence, there is no disproportion in the sample.

Table 1: Global Descriptive Statistics

\begin{tabular}{|l|c|c|c|}
\hline & LMVA & LCAP & LRD \\
\hline Mean & 25.29881 & 25.91636 & 0.707165 \\
\hline Median & 25.15128 & 25.58130 & 0.844356 \\
\hline Maximum & 28.27896 & 28.82974 & 1.363760 \\
\hline Minimum & 22.05495 & 24.27397 & -0.849403 \\
\hline Std. Dev. & 1.657247 & 1.306585 & 0.459357 \\
\hline
\end{tabular}

$\mathrm{L}$ is the log of the variable.S

Source: Author' estimation.

Figure 1 and 2 illustrate the trend of the all variables for the selected countries for the period 1996 to 2015.

Figure 1: The Graphical Presentation of LMVA in Selected Countries

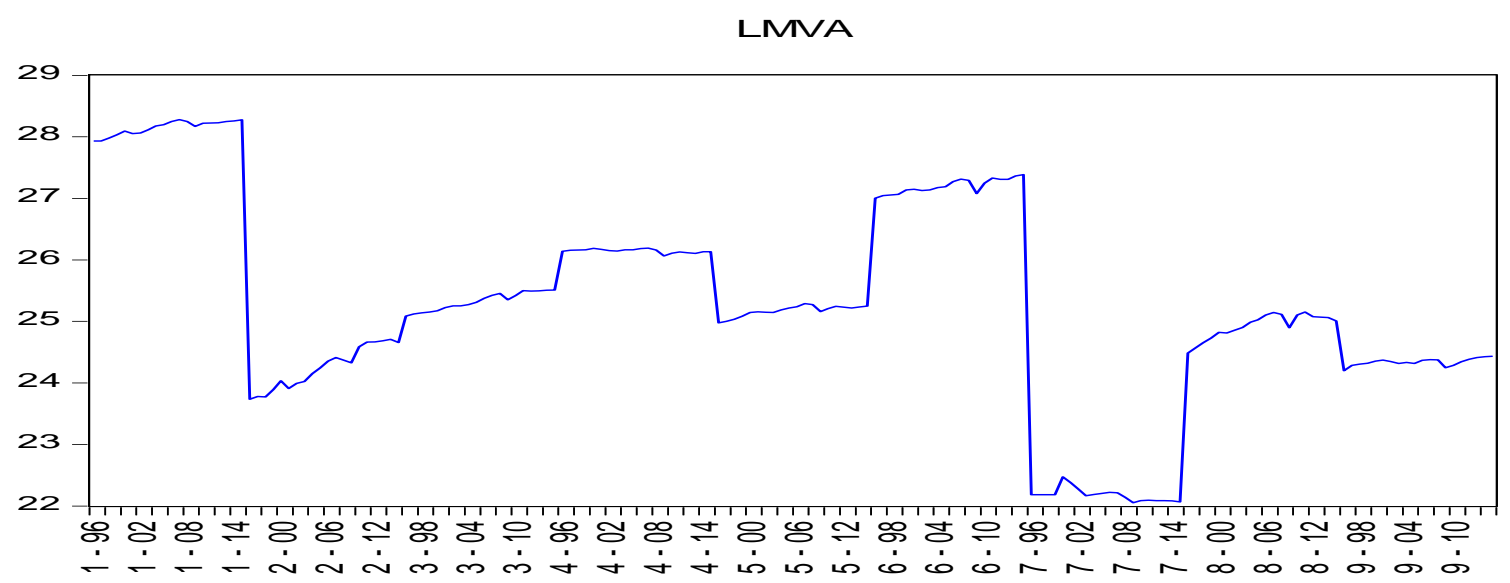


Yönetim ve Ekonomi Arasstrmaları Dergisi / Journal of Management and Economics Research

Cilt/Volume: $16 \quad$ Sayl/Issue: $1 \quad$ Mart/March 2018 ss./pp. 303-314

E. Aydın Doi: http://dx.doi.org/10.11611/yead.416806

Figure 2: The Graphical Presentation of LCAP and LRD in Selected Countries

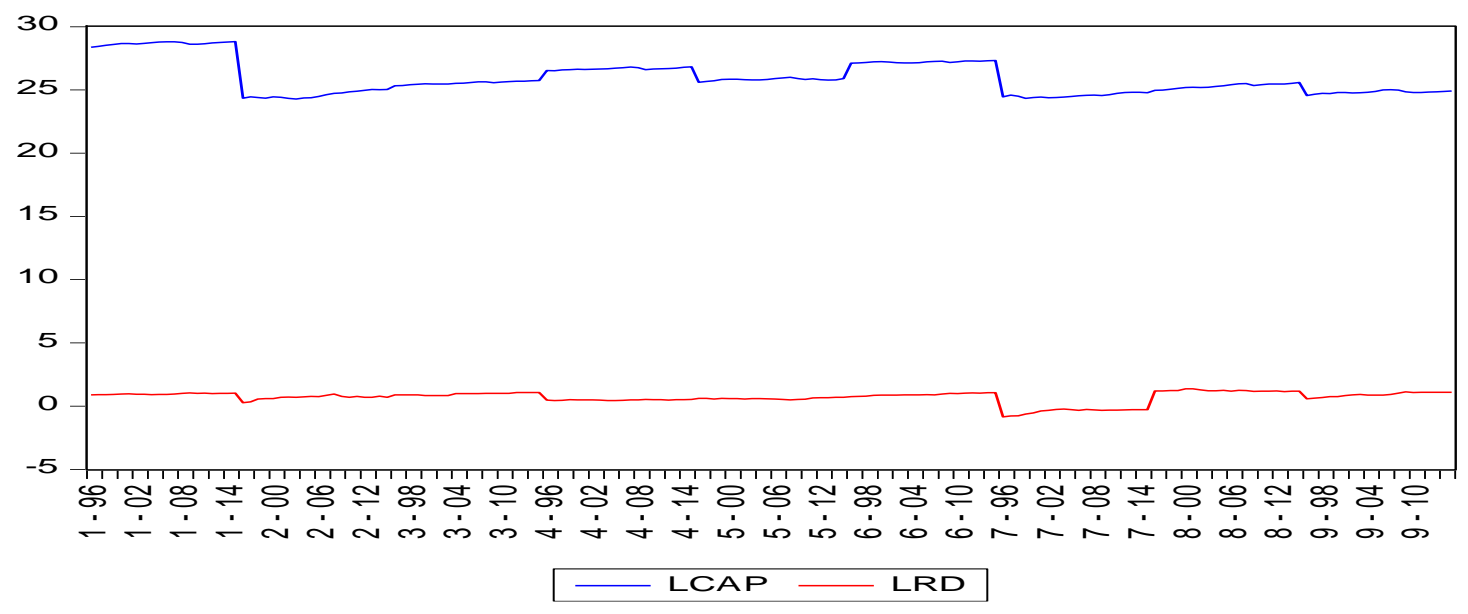

\subsection{Panel Stationarity Test}

After obtaining the descriptive statistics, firstly, the existence of cross-sectional dependence is investigated.

According to Pesaran (2006), ignoring cross-section dependency triggers to substantial bias in estimation of the relationship between the variables (Balan, 2015). This study investigates the presence of cross-sectional dependence across countries through Breusch and Pagan (1980)'s $\mathrm{CD}_{\mathrm{BP}}$ test. The test is useful when $\mathrm{N}$ is fixed and T goes to infinity (Kılıç and Arıca, 2014;160).

The test statistics can be calculated using the following panel data model:

$$
y_{i t}=\alpha_{i}+\beta_{i}{ }^{\prime} \cdot x_{i t}+\mu_{i t} \text { for } \mathrm{i}=1,2, \ldots, \mathrm{N} ; \mathrm{t}=1,2, \ldots, \mathrm{T}
$$

The null and the alternative hypotheses of the test are as follows:

$$
\begin{aligned}
& H_{0}: \operatorname{Cov}\left(\mu_{i t}, \mu_{j t}\right)=0 \text { for all } \mathrm{t} \text { and } i \neq j \\
& H_{0}: \operatorname{Cov}\left(\mu_{i t}, \mu_{j t}\right) \neq 0 \text { for at least some } i \neq j
\end{aligned}
$$

The test statistic developed by Breusch and Pagan (1980) is as follows:

$$
C D_{B P}=T \cdot \sum_{i=1}^{N-1} \sum_{j=i+1}^{N} \hat{\rho}_{i j}^{2} \sim \chi_{N .(N-1) / 2}^{2}
$$

Here $\hat{\rho}_{i j}$ denotes the correlation coefficient among the residuals obtained from individual OLS methods of Equation (2). 
Yönetim ve Ekonomi Arasttrmaları Dergisi / Journal of Management and Economics Research

Cilt/Volume: $16 \quad$ Sayl/Issue: $1 \quad$ Mart/March 2018 ss./pp. 303-314

E. Aydın Doi: http://dx.doi.org/10.11611/yead.416806

According to O'Connell (1998) and Pesaran (2007), the panel unit root tests which do not account for cross-sectional dependence of the contemporaneous error terms cause substantial size distortions. In this study, it is implemented the panel stationarity test proposed by Hadri and Kurozumi (2012) that considers the cross-sectional dependence. Hadri and Kurozumi (2012) consider the following equation:

$$
y_{i t}=k_{t}^{\prime} \varphi_{i}+f_{t} \cdot \gamma_{i}+\varepsilon_{i t}, \varepsilon_{i t}=\phi_{i 1} \cdot \varepsilon_{i t-1}+\ldots+\phi_{i p} \cdot \varepsilon_{i t-p}+v_{i t} \text { for } \mathrm{i}=1, \ldots, \mathrm{N}, \mathrm{t}=1, \ldots, \mathrm{T}
$$

Where $k_{t}^{\prime}$ is deterministic, $k_{t}^{\prime} \varphi_{i}$ is the individual effect while $f_{t}$ is a one-dimensional unobserved common factor, $\gamma_{i}$ is the loading factor, and $\varepsilon_{i t}$ is the individual-specific error.

And Kurozumi (2012) regress $y_{i t}$ on $w_{t}=\left[z^{\prime}{ }_{t}, \bar{y}_{t}, \bar{y}_{t-1}, \ldots, \bar{y}_{t-p}\right]$ in order to correct the problem of cross-sectional dependency and construct the following test statistic (Ener et al. 2017):

$$
\begin{gathered}
Z_{A}=\frac{\sqrt{N} \overline{(S T}-\xi)}{\zeta} \text { where } \overline{S T}=1 / N \cdot \sum_{i=1}^{N} S T_{i} \text { with } S T_{i}=\frac{1}{\hat{\sigma}_{i}{ }^{2} \cdot T^{2}} \sum_{t=1}^{T} S^{w}{ }_{i t} \text {, where } \\
S_{i t}{ }^{w}=\sum_{s=1}^{t} \hat{\varepsilon}_{i s}, \hat{\sigma}_{i}{ }^{2} \text { is the estimator of the long-run variance. }
\end{gathered}
$$

Hadri and Kurozumi (2012)'s estimator of the long-run variance is as follows:

$$
\hat{\sigma}_{i S P C}^{2}=\frac{\hat{\sigma}_{v i}^{2}}{\left(1-\hat{\varpi}_{i}\right)^{2}} \text { where } \hat{\sigma}_{v i}^{2}=1 / T \cdot \sum_{t=1}^{T} \hat{v}_{i t}^{2} \text { and } \widehat{\varpi}_{i}=\min \left\{1-\frac{1}{\sqrt{T}}, \sum_{j=1}^{p} \hat{\varpi}_{i j}\right\} .
$$

Hadri and Kurozumi (2012) constitute the test statistic of $Z_{A}{ }^{S P C}$ as below:

$$
Z_{A}^{S P C}=\frac{1}{\hat{\sigma}_{i S P C}^{2} \cdot T^{2}} \sum_{t=1}^{T}\left(S_{i t}{ }^{w}\right)^{2}
$$

Under a null hypothesis, this test indicates that series have a stationary process, while an alternative hypothesis indicates that series have a unit root process. The test can be used in which $\mathrm{T}<\mathrm{N}$ and $\mathrm{T}>\mathrm{N}$. 
Yönetim ve Ekonomi Arasttrmaları Dergisi / Journal of Management and Economics Research

Cilt/Volume: $16 \quad$ Sayl/Issue: $1 \quad$ Mart/March 2018 ss./pp. 303-314

E. Aydın Doi: http://dx.doi.org/10.11611/yead.416806

Table 2: Results for The Hadri-Kurozumi (2012) Stationary Test and $\mathrm{CD}_{\mathrm{BP}}$ Cross-Sectional

Dependence Test

\begin{tabular}{|c|c|c|c|}
\hline Variable & $\begin{array}{l}Z_{A}^{S P C} \text { stat. (p-value) } \\
\text { at level }\end{array}$ & $\begin{array}{l}Z_{A}^{S P C} \text { stat. (p-value) } \\
\text { at first difference }\end{array}$ & $\mathrm{CD}_{\mathrm{BP}}$ stat. (p-value) \\
\hline LMVA & $-1,8897 \quad(0,97)$ & - & $109,379 * * *(0,00)$ \\
\hline LRD & $-2,0868 \quad(0,98)$ & - & $68,635 * * *(0,00)$ \\
\hline LCAP & $-1,8994 * *(0,05)$ & $-1,2823(0,90)$ & $91,905 * * *(0,00)$ \\
\hline
\end{tabular}

***, ** denote statistical significance at the 1 and $5 \%$ level, respectively $\mathrm{L}$ is the log of the variable.

Source: Author' estimations.

Table 2 reports $\mathrm{CD}_{\mathrm{BP}}$ test results confirming the presence of the cross sectional dependence both in the mostly panel series.

In addition, Table 2 shows the Hadri-Kurozumi (2012) test's results. According to the test, all the variables except for LCAP variable are stationary at the significance level of $1 \%$.

\subsection{Panel Non-Causality Test}

In this study, the panel non-causality test developed by Dumitrescu and Hurlin (2012) was applies to find the causal relationships among the variables. Dumitrescu and Hurlin (2012) test is a simple version of the Granger (1969) non-causality test for heterogeneous panel data models. For each individual, Dumitrescu and Hurlin (2012) consider the following model (Torun et al. 2017):

$$
y_{i, t}=\alpha_{i}+\sum_{k=1}^{K} \gamma_{i}^{(k)} y_{i, t-k}+\sum_{k=1}^{K} \beta_{i}^{\left({ }^{(k)}\right.} x_{i, t-k}+\varepsilon_{i, t} \quad \mathrm{i}=1, \ldots, \mathrm{N} \text { at time } \mathrm{t}=1, \ldots \mathrm{T}
$$

Where $x_{i}=\left(x_{i 1, \ldots,}, x_{i T}\right)^{\prime}$ and $y_{i}=\left(y_{i 1, \ldots,}, y_{i T}\right)^{\prime}$ have a stationary process in $\mathrm{T}$ periods. It is assumed that lag orders $\mathrm{K}$ are identical for all cross-section units of the panel and the panel is balanced. Besides, it is allowed that autoregressive parameters $\gamma_{i}^{(k)}$ and the regression coefficients slopes ${ }_{i}^{\left({ }^{(k)}\right.}$ are constant in time and they vary across groups.

Under the null hypothesis, it is assumed that $\mathrm{x}$ is not Granger cause of $\mathrm{y}$. This hypothesis is denoted as the Homogeneous Non Causality (HNC) hypothesis.

The alternative hypothesis is the Heterogeneous Non Causality (HENC) hypothesis. Under this hypothesis, it is assumed that $\mathrm{x}$ is Granger cause of $\mathrm{y}$ for a subgroup of individuals and ${ }^{\beta_{i}}$ may differ across groups. 
Yönetim ve Ekonomi Araștırmaları Dergisi / Journal of Management and Economics Research

Cilt/Volume: $16 \quad$ Sayl/Issue: $1 \quad$ Mart/March 2018 ss./pp. 303-314

E. Aydın Doi: http://dx.doi.org/10.11611/yead.416806

$Z_{N, T}^{H n c}$, the standardized average statistic, which has asymptotic distribution, for $T, N \rightarrow \infty$ denotes the fact that $T \rightarrow \infty$ first and then $N \rightarrow \infty$ is as follows: $Z_{N, T}^{H n c}=\sqrt{N / 2 K} .\left(W_{N, T}^{H n C}-K\right) \rightarrow N(0,1)$

$\tilde{Z}_{N}^{H n C}$, the standardized average statistic, which has semi-asymptotic distribution, for a fixed T dimension with $T \succ 5+2 K$ converges in distribution (Torun et al. 2017):

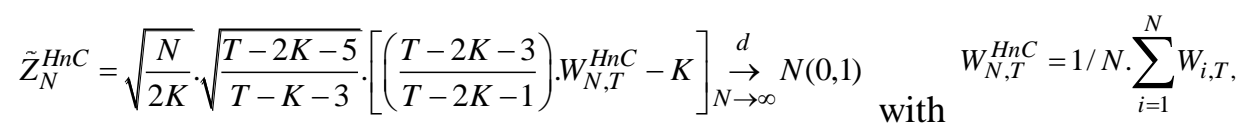

The Dumitrescu and Hurlin (2012)'s test results are shown in Table 3.According to Table 3, capital intensity is Granger causal of manufacturing value added at 0,10 significance level. In addition, the empirical findings in Table 3 suggest that a bidirectional causality relationship running from $R \& D$ to manufacturing value added for the selected 9 leading countries, vice versa.

Table 3: The Results for Dumitrescu and Hurlin (DH) Panel Granger Non-Causality Test

\begin{tabular}{|c|c|c|}
\hline Null Hypothesis & \multicolumn{2}{|c|}{ Test Statistic (P-Value) } \\
\hline \multicolumn{3}{|c|}{ LRD does not Granger Cause LMVA LMVA does not Granger Cause LRD } \\
\hline Zhnc(Asymptotic) & $4,04 * * *(0,00)$ & $1,74 *(0,08)$ \\
\hline \multicolumn{3}{|c|}{ LDCAP does not Granger Cause LMVA LMVA does not Granger Cause CAP } \\
\hline Zhnc(Asymptotic) & $2,00 *(0,05)$ & $0,80(0,28)$ \\
\hline
\end{tabular}

Finally, the equation (1) was estimated by the OLS estimator. The results of the estimation are illustrated in Table 4.

Table 4: Results for Panel Ordinary Least Squares Method

\begin{tabular}{|c|c|c|c|c|}
\hline Variable & Coefficient & Std. Error & t-Statistic & Prob. \\
\hline LDCAP & 0.677228 & 0.067405 & 10.04719 & 0.0000 \\
\hline LRD & 1.675169 & 0.128988 & 12.98705 & 0.0000 \\
\hline C & 8.837631 & 1.540224 & 5.737888 & 0.0000 \\
\hline
\end{tabular}

*** denotesrejection of the null hypothesis at the $1 \%$ level of significance. $\mathrm{L}$ is the log of the variable and $\mathrm{D}$ denotes first difference of the variable.

Dependent Variable: LMVA (d.f. corrected) 
Yönetim ve Ekonomi Arastırmaları Dergisi / Journal of Management and Economics Research

Cilt/Volume: $16 \quad$ Sayl/Issue: $1 \quad$ Mart/March 2018 ss./pp. 303-314

E. Aydın Doi: http://dx.doi.org/10.11611/yead.416806

According to Table 4, both LCAP and LRD have statistically significant effects on MVA. From these empirical findings it can be said that greater capital intensity and R\&D expenditures of GDP, which are the input variables of industry 4.0 process significantly increase manufacturing value added, which is the one of the output variables of the process.

\section{CONCLUSION}

The increasingly competitive environment created by information technology and globalization with high acceleration in the 2000s has radically differentiated the value creation activities of countries and nations and has led them to progress by renewing themselves. Undoubtedly, the advantages of capturing these revolutions (or the disadvantages of missing the opportunities of them) have an important place in the classification of developed, developing and underdeveloped countries, which are frequently used today.

The manufacturing industry, which is accepted as one of the priority effect areas of technological development, will undoubtedly be directly influenced by the changes that Industry 4.0 brings and requires. From this point of view, value-added in manufacturing was taken into account as the core of economic development/growth and the nine leading countries were examined over the period 1996-2015 in this paper.

Empirical results of this study was applied by the Dumitrescu-Hurlin (2012) panel Granger causality test, which takes into account cross-sectional dependence indicate one-way causality from capital intensity to manufacturing value added, two-way causality between R\&D expenditures as a share of GDP and manufacturing value added in the selected country group. In addition, empirical findings showed that greater capital intensity and R\&D expenditures of GDP, which are the input variables of industry 4.0 process significantly increase manufacturing value added, which is the one of the output variables of the process.

This research is important in that it is a preliminary study on the extent to which the value added of the manufacturing industry will be affected by the industry 4.0 process. Further research which include the use of variables other than capital intensity and R \& D expenditure, the addition of new countries outside of these nine countries or the examination of different industries may provide us with additional information on the economic impacts of Industry 4.0 process. 
Yönetim ve Ekonomi Arasttrmaları Dergisi / Journal of Management and Economics Research

Cilt/Volume: $16 \quad$ Sayl/Issue: $1 \quad$ Mart/March 2018 ss./pp. 303-314

E. Aydın Doi: http://dx.doi.org/10.11611/yead.416806

\section{REFERENCES}

Alçın S. (2016) “Endüstri 4.0 ve İnsan Kaynakları”, Popüler Yönetim Dergisi, 63.

Balan, F. (2015) “Testing the Demographic Economic Paradox for Newly Industrialized Countries A Panel Data Analysis", Economic Insights-Trends and Challenges, 67 (2): 1-10.

Breusch T.S and Pagan A.R. (1980) "The Lagrange Multiplier Test and Its Application to Model Specifications in Econometrics”, Rev. Econ. Stud, 47 (1): 239-253.

Drath R. and Horch A. (2014) “Industrie 4.0: Hit or Hype, IEEE Industrial Electronics Magazine”, $8(2)$.

Dumitrescu, Elena Ivona and Hurlin, C. (2012) “Testing for Granger Non-Causality in Heterogeneous Panels", Economic Modelling, 29(4): 1450-1460.

Ener M., Kılıç C., Balan F. and Kurt Ü. (2017), “Entrepreneurship, Political and Financial Stability and Their Impact on Economic Growth: A Panel Data Analysis for Selected EU Countries', 13th International Conference on Knowledge, Economy Management Proceedings.

Fırat, Seniye Ümit ve Fırat, Oktay Zihni. (2017) “'Sanayi 4.0 Üzerine Karşılaştırmalı Bir İnceleme: Kavramlar, Küresel Gelişmeler ve Türkiye’, Toprak İşveren Dergisi, 114.

Hadri, K., and Kurozumi, E. (2012) "A Simple Panel Stationarity Test in the Presence of Serial Correlation and a Common Factor', Economics Letters, 115, 31-34.

Kılıç C., Arıca Balan F. (2014) "Economic Freedom Inflation Rate and Their Impact on Economic Growth A Panel Data Analysis', Romanian Journal of Economic Forecasting, 17(1): 160-176.

Industrie 4.0, https://www.i-scoop.eu/industry-4-0/ (01.03.2018)

Industry 4.0: Building The Digital Enterprice (2016), https://www.pwc.com/gx/en/industries/industries-4.0/landing-page/industry-4.0-building-yourdigital-enterprise-april-2016.pdf

O'Connell, P. (1998) "The Overvaluation of Purchasing Power Parity", Journal of International Economics, 44: 1-19.

Öztürk, E., Koç, K. H. (2017) “Endüstri 4.0 ve Mobilya Endüstrisi”, 4. Uluslararas1 Mobilya ve Dekorasyon Kongresi, Düzce - Türkiye.

Pesaran, M. H. (2006) "Estimation and Inference in Large Heterogeneous Panels with Multifactor Error Structure", Econometrica, 74: 967-1012. 
Yönetim ve Ekonomi Arasttrmaları Dergisi / Journal of Management and Economics Research Cilt/Volume: $16 \quad$ Sayl/Issue: $1 \quad$ Mart/March 2018 ss./pp. 303-314

E. Aydın Doi: http://dx.doi.org/10.11611/yead.416806

Pesaran, M.H. (2007) “A Simple Panel Unit Root Test in The Presence of Cross Section Dependence”, Journal of Applied Econometrics, 22: 265-312.

Plex Manufacturing Blog, https://www.plex.com/blogs/industry-4-0-advancements-in-manufacturingtechnology.html (01.03.2018)

Torun M., Kılıç C., Balan F. (2017) “The Effects of Political Risk and GDP on Oil Product Imports: A Panel Analysis for Selected Oil-Dependent Countries", International Congress of Energy Economy and Security (ENSCON)

Türkiye'nin Endüstri 4.0 Platformu, http://www.endustri40.com/endustri-tarihine-kisa-bir-yolculuk/ $(01.03 .2018)$

World Bank, http://data.worldbank.org/indicator, (01.03.2018) 